\title{
HISTAMINE AS A NEUROTRANSMITTER IN THE STOMATOGASTRIC NERVOUS SYSTEM OF THE SPINY LOBSTER $^{1}$
}

\author{
BRENDA J. CLAIBORNE ${ }^{2}$ and ALLEN I. SELVERSTON
}

Department of Biology, University of California, San Diego, La Jolla, California 92093

Received July 13, 1983; Revised November 4, 1983; Accepted November 4, 1983

\begin{abstract}
Histamine is a putative neurotransmitter in mammals and molluses, but its role in the nervous systems of other animals is not known. This study examines the possibility that histamine is a neurotransmitter in an arthropod. Results show that first, 14 neurons in the stomatogastric ganglion of the spiny lobster respond to histamine. The response is inhibitory, is mediated by an increased conductance to chloride, and desensitizes with repeated applications of histamine. These same 14 neurons receive one type of synaptic potential from two extrinsic neurons, the "through-fibers" of the inferior ventricular nerve. This synaptic potential is also inhibitory, is mediated by an increased conductance to chloride, and is blocked when histamine receptors are desensitized. Second, assays of endogenous histamine indicate that histamine is distributed nonuniformly throughout the stomatogastric nervous system and that its distribution correlates with the axonal pathways and terminal arborizations of the inferior ventricular nerve through-fibers. Lastly, histamine is present in relatively high concentrations in the cell bodies of the through-fibers, whereas it is not detectable in other neurons in the stomatogastric system. These results suggest that histamine may be a transmitter in the lobster.
\end{abstract}

The stomatogastric nervous system of the lobster has been used to elucidate a number of cellular mechanisms underlying the generation and control of rhythmic behavior (Selverston et al., 1976; Raper, 1980; Eisen and Marder, 1982; Miller and Selverston, 1982a, b; Russell and Hartline, 1982). Recent work has focused on the role of monoamines in this system and has shown that dopamine is present in neurons (Kushner and Maynard, 1977; Kushner and Ono, 1978) and that it may mediate patterned activity (Kushner, 1979b; Anderson, 1980; Anderson and Barker, 1981). Because preliminary evidence indicated that histamine was present in stomatogastric tissue and that some neurons responded to it (E. Marder and R. McCaman, personal communication; Anderson, 1980 ), the present investigation was undertaken to examine the possibility that histamine is a transmitter in

\footnotetext{
${ }^{1}$ We thank Dr. Richard McCaman for his generous help with the histamine assays and the use of his laboratory facilities, Judy Stetzler for technical assistance, and Drs. Eve Marder, John Miller, Joyce Ono, and Richard McCaman for criticizing the manuscript. This work was supported in part by Grant NS09322 from the National Institutes of Health to A. I. S. and Predoctoral Training Grant GM07153 from the United States Public Health Service to B. J. C.

${ }^{2}$ To whom reprint requests should be addressed, at Developmental Neurobiology Laboratory, The Salk Institute for Biological Studies, P. O. Box 85800, San Diego, CA 92138.
}

the lobster. Histamine is a putative neurotransmitter in the mammalian central nervous system (see reviews by Schwartz, 1977; Schwartz et al., 1979, 1980) and has been shown to be a transmitter in the molluscan central nervous system (Weinreich, 1978; McCaman and Weinreich, 1982). Its functional role in other animals has not been investigated.

The stomatogastric nervous system controls the rhythmic movements of the lobster foregut (Morris and Maynard, 1970). One ganglion in this system, the stomatogastric ganglion, is particularly advantageous for physiological and pharmacological studies because it contains only 30 neurons, all identifiable, that generate patterned activity (Marder, 1976; Selverston and Miller, 1980; Miller and Selverston, 1982a, b; Eisen and Marder, 1982; E. Marder and J. S. Eisen, submitted for publication). Although neurons in this ganglion produce patterned activity without receiving peripheral feedback, the rate and pattern of activity are influenced by axons from more central ganglia (Russell, 1976, 1979) which enter the ganglion via the stomatogastric nerve (SN). Two of these axons are known to be the "through-fibers" of the inferior ventricular nerve (IVN). The IVN through-fibers, also called IVN command interneurons, are thought to be the only axons in the IVN which enter the SN (Dando and Selverston, 1972; Kushner, 1979a; Russell 
and Hartline, 1981) and hence can be selectively activated in the SN by extracellular stimulation of the IVN. Previous investigations have shown that the throughfibers make both inhibitory and excitatory synapses onto certain stomatogastric neurons, and they can induce alterations in either the rate or pattern of activity produced by the ganglion (Dando and Selverston, 1972; Selverston et al., 1976; Sigvardt and Mulloney, 1982a, b).

In the first part of the study reported here, we found that exogenous histamine inhibits 14 of the neurons in the stomatogastric ganglion. An examination of the reported synaptic connections in the ganglion showed that these same 14 neurons receive inhibitory postsynaptic potentials from the IVN through-fibers (Dando and Selverston, 1972; Selverston et al., 1976; Sigvardt and Mulloney, 1982a, b). In the second part of this study, whole nerves and ganglia were assayed for histamine. Data indicate that of the various nerves in the stomatogastric system, the IVN contains the highest concentration of histamine, and furthermore, that the distribution of histamine throughout the stomatogastric system correlates with the axon pathways and terminal arborizations of the through-fibers.

Because these results suggested that the IVN throughfibers might use histamine as a transmitter, a separate study, summarized here and reported in detail elsewhere, was undertaken to locate the cell bodies of the throughfibers (Claiborne, 1981b; Claiborne and Selverston, 1983). Briefly, following cobalt backfilling of the IVN, two cells were stained at the base of the IVN in the brain. Intracellular stimulation of these cells in an in vitro preparation showed that their axons traveled from the IVN to the SN and, although strict tests for monosynapticity were not done, that action potentials evoked in the cell bodies elicited postsynaptic responses in specific stomatogastric neurons which corresponded to the postsynaptic responses elicited by extracellular stimulation of the IVN.

In the last part of the work reported here, we assayed these cells (the "IV neurons") and found that they contain detectable levels of histamine, whereas other neurons in the stomatogastric system do not. These results are discussed in terms of the possibility that histamine may function as a transmitter in the lobster stomatogastric system.

Portions of this work have been reported in abstract form (Claiborne, 1980a, b, 1981a).

\section{Materials and Methods}

Animals. Spiny lobsters (Panulirus interruptus) were obtained from local fishermen (San Diego, CA) and kept in running seawater aquaria. Animals of both sexes, weighing between 0.4 and $1.5 \mathrm{~kg}$, were used. The esophagus and stomach were removed from the animal, and the stomatogastric nervous system and supraesophageal ganglion were dissected free as described previously (Mulloney and Selverston, 1974). The nervous tissue was pinned out in a Sylgard-coated dish and covered with Panulirus saline.

Saline. Normal Panulirus saline was composed of the following: $486.9 \mathrm{mM} \mathrm{Na} \mathrm{ma}^{+}, 519 \mathrm{mM} \mathrm{Cl}{ }^{-}, 12.7 \mathrm{mM} \mathrm{K}, 13.7$ $\mathrm{mM} \mathrm{Ca}{ }^{+2}, 10 \mathrm{mM} \mathrm{Mg}{ }^{+2}, 13.9 \mathrm{mM} \mathrm{SO}{ }_{4}^{-2}, 4.9 \mathrm{mM} \mathrm{N}$ - tris(hydroxymethyl)-methyl-2-aminoethanesulfonic acid (Sigma), and $4.9 \mathrm{~mm}$ HEPES (Sigma) buffers. The $\mathrm{pH}$ was adjusted to 7.45 by the addition of $\mathrm{NaOH}$.

To prepare calcium-free saline, $\mathrm{MgSO}_{4}$ was substituted on an equimolar basis for $\mathrm{CaCl}_{2}$. Saline containing twice normal potassium was made by adding $12.7 \mathrm{mM} \mathrm{KCl}$ to normal saline without compensation for osmolarity changes. Low chloride saline was made by substituting $\mathrm{Na}_{2} \mathrm{SO}_{4}$ for $\mathrm{NaCl}$ and adjusting the osmolarity with sucrose. This substitution was done in calcium-free saline to avoid precipitation of $\mathrm{Ca}_{2} \mathrm{SO}_{4}$.

Histamine responses. The stomatogastric nervous system was prepared for recording, and neurons in the stomatogastric ganglion were identified physiologically (Russell, 1976; Selverston et al., 1976). Following neuronal identification, spontaneous activity was sometimes reduced by cutting the stomatogastric nerve. Microelectrodes for intracellular recordings were filled with either $3 \mathrm{M} \mathrm{KCl}$ or $0.5 \mathrm{M} \mathrm{K}_{2} \mathrm{SO}_{4}$ and had resistances between 35 and 50 megohms. In the majority of experiments, two electrodes were inserted into a neuron, one for recording and one for injecting current. Either a silver-chloride wire or an agar bridge was used as a bath ground. Conventional electrophysiological equipment was used to record transmembrane voltages and applied current.

Histamine was applied to somal membranes using an iontophoretic pipette filled in most cases with $1 \mathrm{M}$ histamine dihydrochloride (Calbiochem) dissolved in distilled $\mathrm{H}_{2} \mathrm{O}$ (pH 4.5); responses could also be elicited with 0.1 and $0.5 \mathrm{M}$ histamine. Iontophoretic current pulses (+) were usually $30 \mathrm{msec}$ in duration, but were occasionally as long as $100 \mathrm{msec}$. Holding currents of approximately $5 \mathrm{nA}$ were routinely used. Control iontophoresis of saline, $\mathrm{pH}$ of 4.5 , did not elicit responses.

The iontophoretic pipette was positioned within $20 \mu \mathrm{m}$ of a soma, a pulse of histamine was ejected, and resulting voltage or conductance changes were recorded. If no response was elicited, the pipette was repositioned several times and the procedure was repeated. In a few experiments, histamine was applied iontophoretically to the neuropil region while the ganglion was bathed in calcium-free, high-magnesium saline which blocks chemical synapses in this preparation. This procedure was generally not employed because of the extensive electrical coupling among stomatogastric neurons. Neuronal responses were also recorded during bath application of histamine. Histamine $\left(10^{-5}\right.$ to $\left.10^{-4} \mathrm{M}\right)$ was dissolved in calcium-free, high-magnesium saline and perfused over the ganglion at a rate of $25 \mathrm{ml} / \mathrm{min}$, resulting in a complete change of saline within $30 \mathrm{sec}$.

The following histamine $\mathrm{H}_{1}$ antagonists were dissolved in Panulirus saline at concentrations between $5 \times 10^{-5}$ and $2 \times 10^{-4} \mathrm{M}$ and were superfused over the ganglion: chlorpheniramine, pyrilamine (Chemalog), diphenhydramine, and promethazine (Smith, Kline and French). The histamine $\mathrm{H}_{2}$ antagonists cimetidine and metiamide (both gifts of Smith, Kline and French) were dissolved in $\mathrm{HCl}$, neutralized with $\mathrm{NaOH}$, and diluted in saline to concentrations between $5 \times 10^{-5}$ and $5 \times 10^{-4} \mathrm{M}$. Picrotoxin and $d$-tubocurarine (Sigma) were dissolved in saline at $2 \times 10^{-4} \mathrm{M}$.

Histamine assay. Either entire ganglia and nerves or neuronal cell bodies were dissected and assayed for his- 


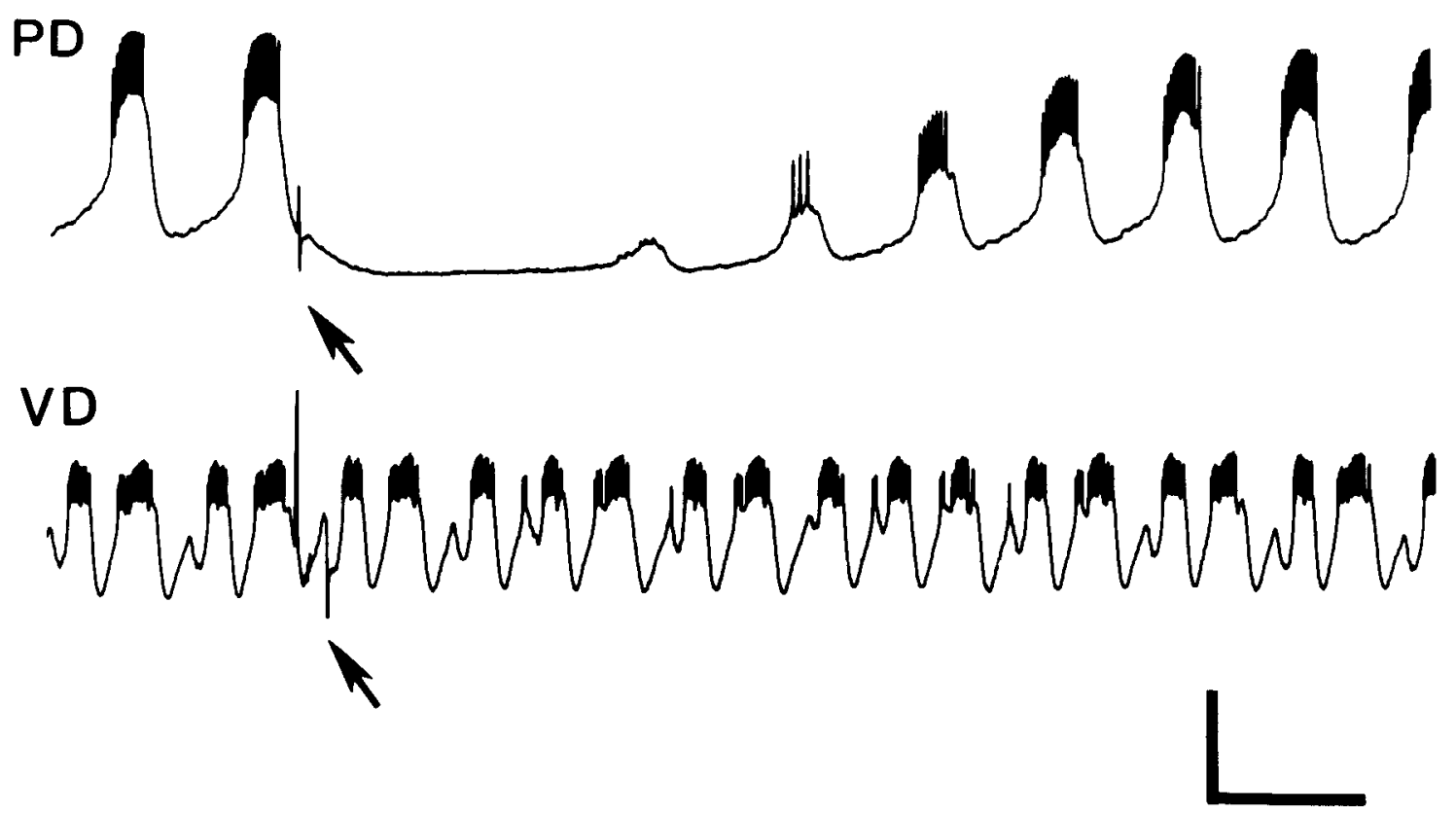

Figure 1. Histamine response in a PD neuron. Intracellular recordings from a PD and a VD neuron showing the normal rhythmic activity. Histamine was applied iontophoretically (arrous) to the somata. The attenuated action potentials in the PD were abolished, as were the slow-wave oscillations underlying the bursts. The VD was unaffected by histamine, even though the histamine pulse was much longer in duration $(200 \mathrm{msec})$ than the pulse used to affect the PD neuron (30 msec). The resting membrane potentials of the PD and VD neurons were -60 and $-59 \mathrm{mV}$, respectively. Scale bars $=20 \mathrm{mV}, 1 \mathrm{sec}$.

tamine. For assays of entire ganglia or nerves, tissue samples were removed from the saline and loaded directly into microtubes containing $0.1 \mathrm{~N} \mathrm{HCl}$ and $20 \mathrm{mM}$ mercaptoacetic acid. The amount of $\mathrm{HCl} /$ mercaptoacetic acid was proportional to the size of the tissue sample and varied from $10 \mu \mathrm{l}$ for the stomatogastric ganglion to 120 $\mu \mathrm{l}$ for the inferior esophageal nerve (ION). Samples were either assayed immediately or were stored at $-70^{\circ} \mathrm{C}$ for several days. Single cell bodies or clusters of cell bodies were isolated, using the protocol of Ono and McCaman (1980), and were loaded into microtubes. Either 5 or 10 $\mu \mathrm{l}$ of $0.1 \mathrm{~N} \mathrm{HCl} / 20 \mathrm{mM}$ mercaptoacetic acid were added to each tube.

Histamine was measured using the procedure of Taylor and Synder (1972), as modified by Weinreich et al. (1975). For the assays of whole ganglia and nerves, histamine standards and blanks were carried through the entire procedure. Recovery of standards, in the presence or absence of tissue extracts, ranged between 80 and $100 \%$, and the results were corrected for recoveries. Radioactivity was directly proportional to the amount of histamine standards up to $5.0 \mathrm{pmol}$. Greater than $80 \%$ of the radioactivity co-chromatographed with l-methylhistamine (Calbiochem) in two solvent systems. Protein in the tissue samples was measured using the Lowry procedure with bovine albumin $(0.3$ to $5.0 \mu \mathrm{g})$ standards. For the measurement of histamine in cell bodies, the sensitivity of the assay permitted the reliable detection of as little as $0.02 \mathrm{pmol}$ of histamine (Ono and McCaman, 1980).

\section{Results}

Histamine response. The stomatogastric ganglion contains 30 neurons of which 23 are motor neurons control- ling muscles of either the pyloric region or the gastric mill region of the stomach. The remaining seven are interneurons. Each neuron type in the ganglion was tested for histamine responsiveness in at least three preparations, except interneuron 1 which was examined only twice.

Fourteen of the neurons in the ganglion responded to the iontophoretic application of histamine to their somata. These were the two pyloric dilators (PDs), the four gastric mill neurons (GMs), the two lateral posterior gastrics (LPGs), the five EX cells (interneurons), and the anterior burster ( $\mathrm{AB}$, also an interneuron). Figures 1 and 2 show examples of these responses in the PD, GM and LPG neurons. Figure 1 also shows the absence of a response in a ventral dilator neuron (VD). Although the distribution of histamine receptors was not examined in detail, histamine responses were most easily found in $\mathrm{PD}, \mathrm{AB}$, and EX neurons. Before a response was elicited in the GM or LPG neurons, the iontophoretic pipette often had to be repositioned several times. Iontophoretic application into the neuropil region elicited hyperpolarizing responses in the two neurons tested, the PD and GM neurons. Bath application of histamine also elicited hyperpolarizing responses in all of the neurons which responded to iontophoretic application.

Only one type of histamine response was found in stomatogastric neurons, and it was always mediated by a conductance increase, the amount of which varied depending on the size and proximity of the histamine pulse. It was not unusual to see a 2- to 3-fold conductance increase at the peak of the response, reflecting a change in input resistance from approximately 10 to 3 megohms. This is illustrated in Figure 3, which shows the conductance increase following an iontophoretic application of 


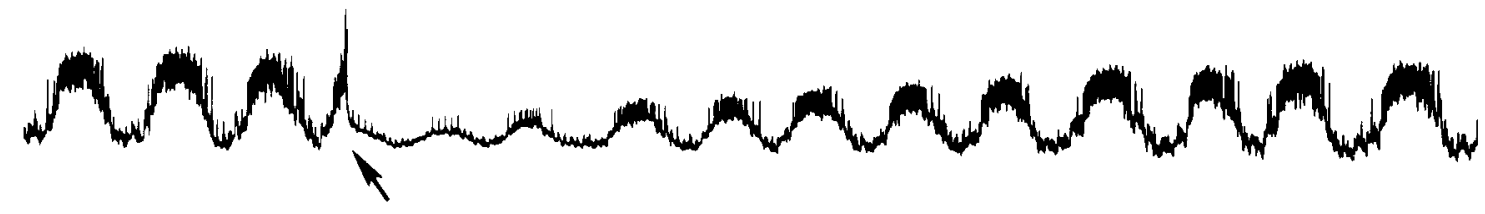

LPG
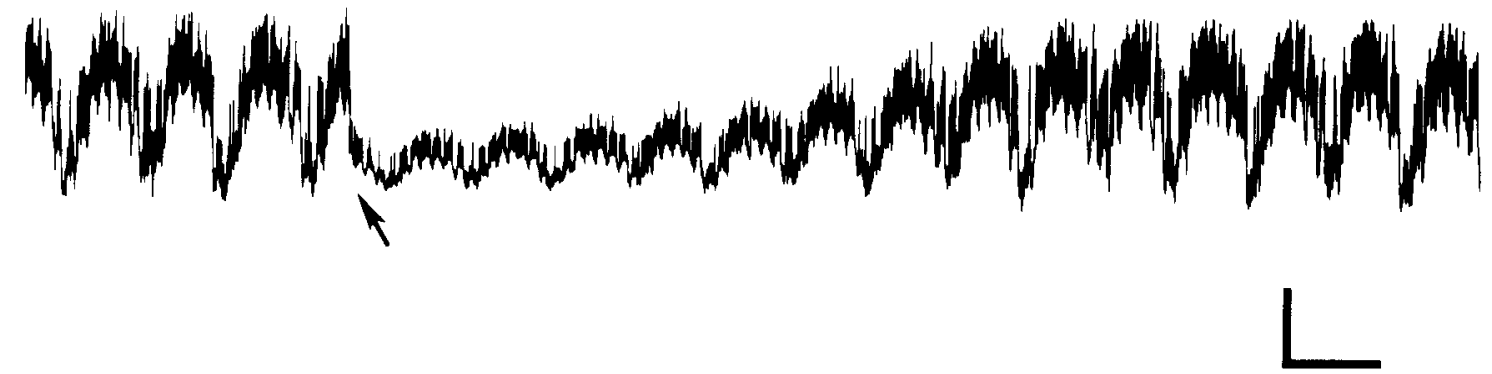

Figure 2. Histamine responses in a GM and an LPG neuron. Intracellular recordings from these neurons show their normal patterned activity. Note the decrease in amplitude of both the attenuated action potentials and the slow-wave oscillations, following histamine application (arrows). The resting membrane potentials of the GM and LPG neurons were $-61 \mathrm{mV}$ and -62 $\mathrm{mV}$, respectively. Scale bars $=20 \mathrm{mV}, 4 \mathrm{sec}$.

histamine, and in Figure 4, which shows the conductance increase in the presence of bath-applied histamine.

The voltage change accompanying the response was usually in the hyperpolarizing direction (Figs. 1 and 2), but it was occasionally depolarizing in neurons with low resting potentials. In no cases was a response found which was depolarizing at all membrane potentials; the reversal potential was always within $10 \mathrm{mV}$ of the resting potential. In some neurons, the reversal potential corresponded to the resting membrane potential such that no voltage change was observed (Fig. 3 ).

The reversal potential was examined in detail in EX neurons and found to average within $1 \mathrm{mV}$ of the resting potential (Fig. 5). In $13 \mathrm{EX}$ neurons tested, the average reversal potential was $-59.9 \pm 1.8$ (mean \pm SEM) $\mathrm{mV}$, while the average resting potential was $-60 \pm 2.2 \mathrm{mV}$. Similar values were obtained using GM neurons.

The reversal potential value suggested that the response was mediated by chloride ions, and hence the reversal potential was recorded after changes in chloride and potassium ions. First, after intracellular injection of chloride ions into $8 \mathrm{EX}$ neurons from different animals, the reversal potentials depolarized, and the resting potentials hyperpolarized slightly (Fig. 6 and Table I). Both reversal and resting potentials returned to control values within $10 \mathrm{~min}$.

Second, in the presence of saline containing two times the normal external potassium concentration, the reversal potentials depolarized by a few millivolts, but the resting potentials depolarized an even greater amount (Table I).

Third, in the presence of saline with half the normal chloride concentration, the reversal potential depolarized $9 \mathrm{mV}$ (Table I), while the resting potential depolarized by $7 \mathrm{mV}$. When the ganglion was returned to normal saline, the reversal potential and the resting potential hyperpolarized $6 \mathrm{mV}$ relative to control values and then returned to the control potentials within $15 \mathrm{~min}$. The resting potential changes in these experiments suggest that there is a high resting chloride permeability in stomatogastric neurons (see "Discussion").

Pharmacological experiments showed that none of the histamine $\mathrm{H}_{1}$ or $\mathrm{H}_{2}$ antagonists blocked the histamine response. However, curare at a concentration of $2 \times 10^{-4}$ $\mathrm{M}$ did reversibly block the response (Fig. 7). Curare did not affect the membrane resistance of stomatogastric neurons (as measured with intracellular current pulses or ramps) or the reversal potential of the histamine response (data not shown). Picrotoxin, known to block some synaptic potentials in this ganglion (Maynard and Walton, 1975; Bidaut, 1980; Eisen and Marder, 1982; E. Marder and J. S. Eisen, submitted for publication), had no effect on the histamine response, nor did it affect the membrane resistance of stomatogastric neurons (data not shown).

IVN through-fiber synapses. Previous work has shown that stimulation of the IVN through-fibers elicits both inhibitory and excitatory synaptic potentials in stomatogastric neurons (see "Discussion"). Because we found that the same 14 neurons which receive inhibitory potentials from the through-fibers are inhibited by exogenous histamine, we examined several properties of the through-fiber synapses, including the reversal potential and ionic dependence of the inhibitory responses, and the effects of antagonists and histamine receptor desensitization on both inhibitory and excitatory potentials.

To characterize the postsynaptic effects of the through-fibers on neurons in the stomatogastric ganglion, the stomatogastric nervous system was prepared for recording, and extracellular stimulating electrodes 
EX

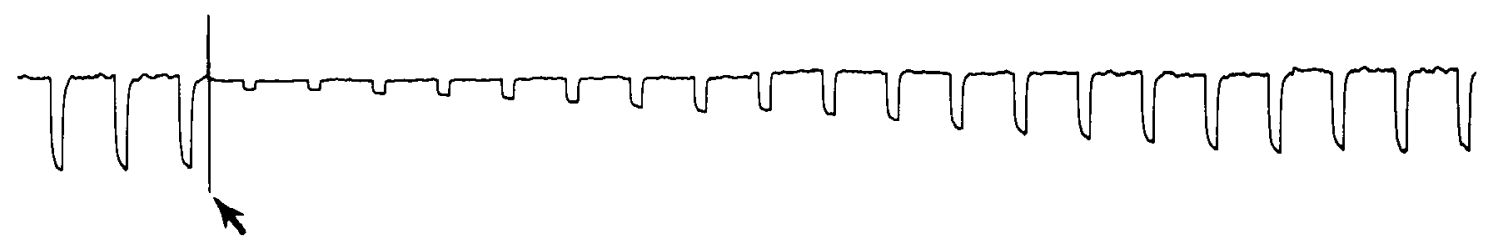

Figure 3. Increase in membrane conductance in response to histamine. Histamine was applied iontophoretically (arrow) to the soma of an EX cell. Constant current pulses $(1 \mathrm{nA})$ were injected through a second electrode. In this experiment, the reversal potential of the response was coincident with the resting membrane potential $(-61 \mathrm{mV})$. Scale bars $=5 \mathrm{mV}, 4 \mathrm{sec}$.

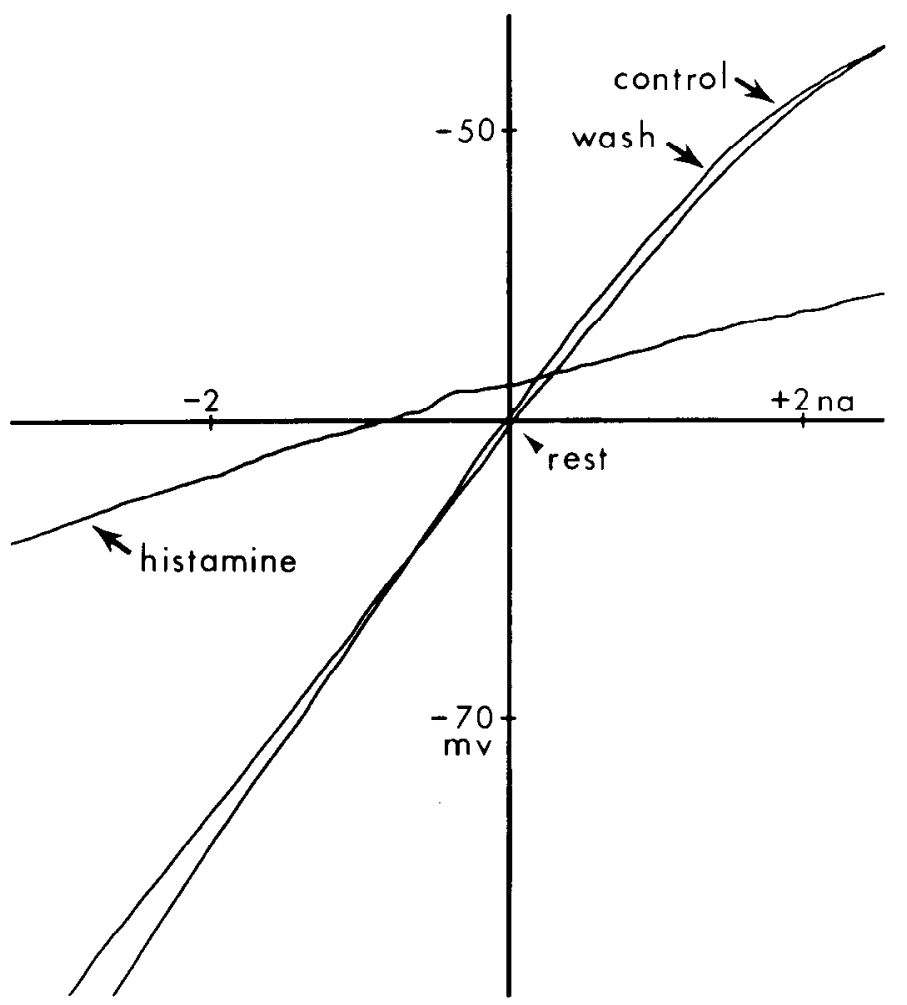

Figure 4. Response to bath application of histamine. Histamine $\left(10^{-4} \mathrm{M}\right)$ was applied to an EX1 neuron in calcium-free, high-magnesium saline. A ramp of current was injected into the cell through one electrode, and the voltage response was recorded with a second electrode. The current-voltage plots shown here were made by feeding the current monitor and cathode follower outputs directly into an $X-Y$ plotter. Note change in the membrane potential and the large increase in conductance in the presence of histamine. EX1 neurons are not known to be electrically coupled to any other neurons (Graubard, 1978).

were placed on the IVN. Because through-fiber synaptic potentials elicited by single pulse stimulation are small and difficult to record, the IVN was stimulated with brief trains of pulses at various frequencies, with current pulses of less than $1 \mathrm{msec}$. This stimulation paradigm

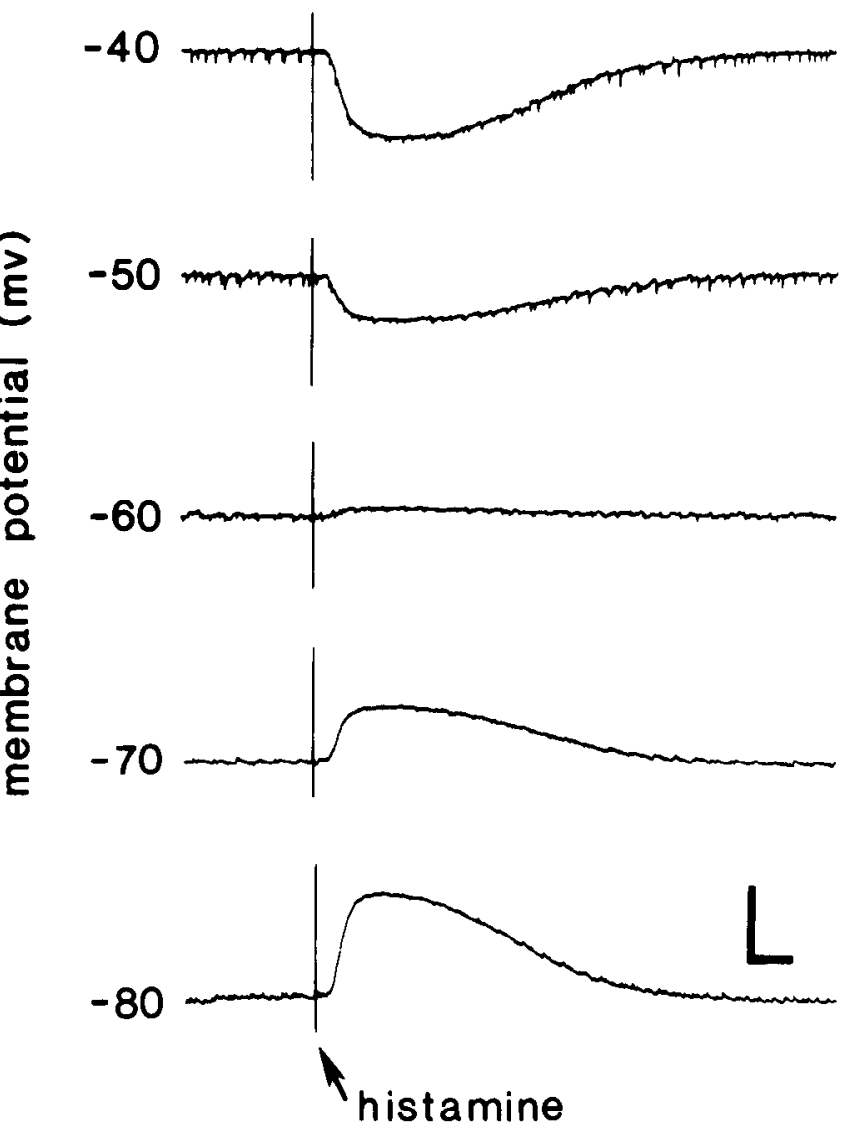

Figure 5. Reversal potential of the histamine response. Histamine was applied iontophoretically (arrow) to the soma of an EX neuron, and the membrane potential was moved using a current electrode filled with $0.5 \mathrm{M} \mathrm{K}_{2} \mathrm{SO}_{4}$. The reversal potential was within a few millivolts of the resting membrane potential $(-60 \mathrm{mV})$. Spontaneous postsynaptic potentials are visible in these recordings. Scale bars $=10 \mathrm{mV}, 2$ sec.

resulted in facilitated and summed responses in EX, GM, and PD neurons.

The IVN through-fiber inhibitory potentials are known to be mediated by an increased conductance (Sigvardt and Mulloney, 1982a). The reversal potential 
a.Control
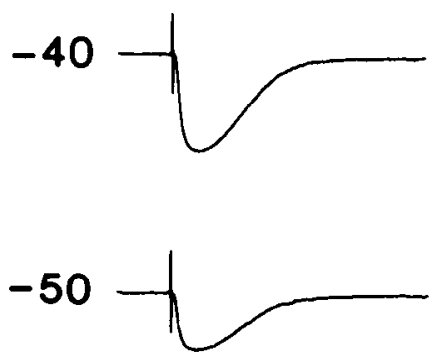

$-60$
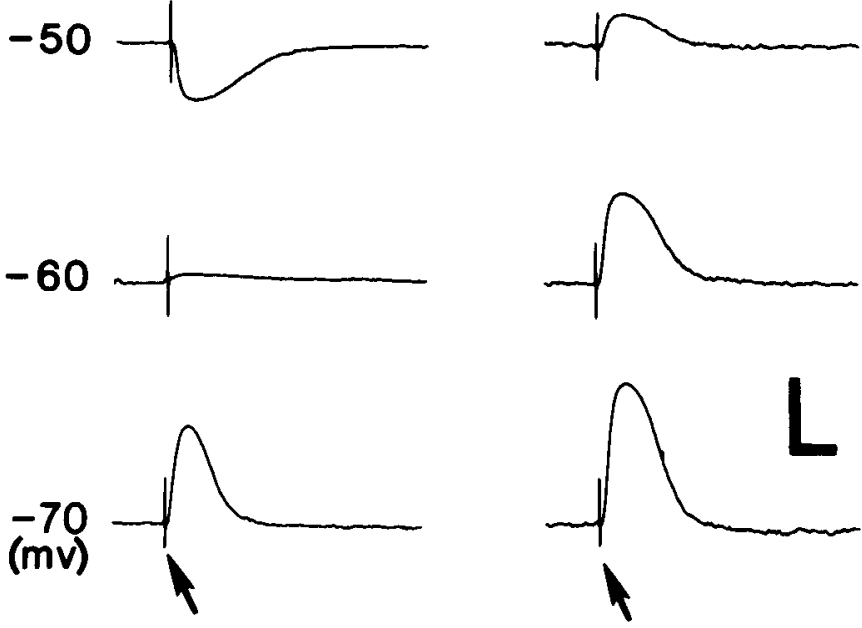

Figure 6. Reversal potential of the histamine response before and after injection of chloride ions. Histamine was applied iontophoretically (arrows) to the soma of an EX neuron, and the membrane potential was moved with a second electrode. $a$, Reversal potential before chloride injection. Resting membrane potential was $-60 \mathrm{mV}$. $b$, Reversal potential after chloride injection. Chloride ions were injected by holding the membrane potential of the cell at $-120 \mathrm{mV}$ for 15 min with a $3 \mathrm{M} \mathrm{KCl}$ electrode. The resting membrane potential shifted to $-59 \mathrm{mV}$. The reversal potential (determined by plotting the amplitude of the response versus the membrane potential) in this experiment depolarized by $15 \mathrm{mV}$ following chloride injection. Scale bars $=10 \mathrm{mV}, 2$ sec. of a through-fiber inhibitory synaptic potential in an EX neuron is shown in Figure 8. Measurements of the reversal potentials in four different EX neurons (with average resting potentials of $-61 \mathrm{mV}$ ) gave an average reversal potential value of $-72 \mathrm{mV}$. Similar values were obtained for the reversal potential in GM and PD neurons. Injection of chloride ions into EX neurons caused the reversal potential to depolarize by an average of $10 \mathrm{mV}$, and the resting potential to hyperpolarize by a few millivolts. This result is illustrated graphically for one EX neuron in Figure 9. In saline containing two times the normal potassium concentration, the reversal potential depolarized an average of $6 \mathrm{mV}$, while the resting potential depolarized an average of $8 \mathrm{mV}$ (Fig. 9). These reversal potentials were all measured by recording from neuronal somata and, due to the cable properties of stomatogastric neurons, are, therefore, more hyperpolarized than the "actual" reversal potentials at the synaptic site (see "Discussion").

All of the histamine antagonists listed under "Materials and Methods" were tested on the through-fiber synaptic responses. Curare blocked both the excitatory

\section{TABLE I}

Shifts in the reversal potential of the histamine response after changes in $\mathrm{Cl}^{-}$and $\mathrm{K}^{+}$ions

All measurements were obtained from EX neurons, and reversal potentials were determined by plotting the amplitudes of the response versus the membrane potential. Shifts in the resting membrane potentials after the ionic changes are given in the bottom panel. Chloride ions were injected by holding the membrane potential at $-120 \mathrm{mV}$ for 15 min with a $3 \mathrm{M} \mathrm{KCl}$ electrode. One-half normal $\mathrm{Cl}^{-}$saline contained $260 \mathrm{mM} \mathrm{Cl}^{-}$and $2 \times$ normal $\mathrm{K}^{+}$contained $25.4 \mathrm{mM} \mathrm{K}^{+}$. Values given are the mean \pm SEM for the number of separate determinations $(n)$.

\begin{tabular}{lccc}
\hline & $\begin{array}{c}\text { Inject } \mathrm{Cl}^{-} \\
(n=8)\end{array}$ & $\begin{array}{c}1 / 2 \mathrm{Cl}^{-} \\
(n=5)\end{array}$ & $\begin{array}{c}2 \times \mathrm{K}^{+} \\
(n=13)\end{array}$ \\
\hline Reversal potential & $+8.3 \pm 1.5$ & $+9.6 \pm 1.7$ & $+4.3 \pm 0.5$ \\
Resting potential & $-1.5 \pm 1.3$ & $+7.2 \pm 1.5$ & $+7.4 \pm 0.9$ \\
\hline
\end{tabular}

\section{a. Control}

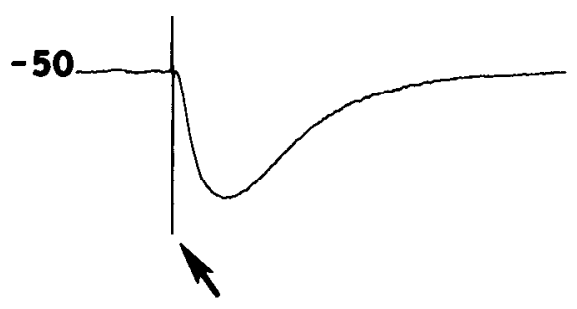

b. Curare

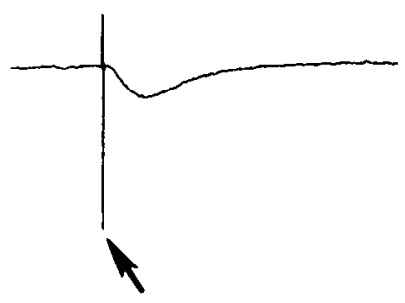

c.Wash

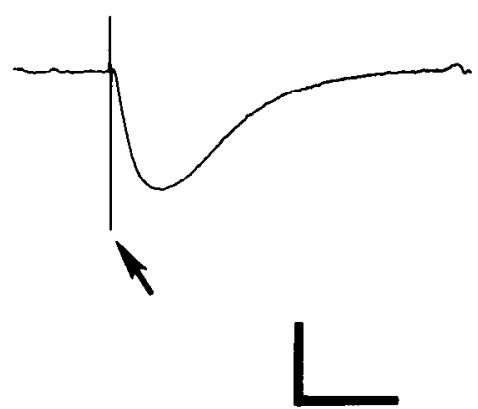

Figure 7. Histamine response is reversibly blocked by $d$-tubocurarine. Histamine was applied iontophoretically (arrows) to the soma of an EX neuron. Iontophoretic current was constant for each application. $a$, Histamine response in normal saline. $b$, Histamine response was reduced after perfusing the ganglion with $2 \times 10^{-4} \mathrm{M}$ curare for $5 \mathrm{~min}$. Longer perfusion times (10 min or more) reversibly blocked the entire response. Curare by itself had no effect on the membrane resistance of stomatogastric neurons, as measured with intracellular injection of current pulses or ramps. $c$, Histamine response following 20 -min wash with normal saline. Scale bars $=10 \mathrm{mV}, 4 \mathrm{sec}$. 

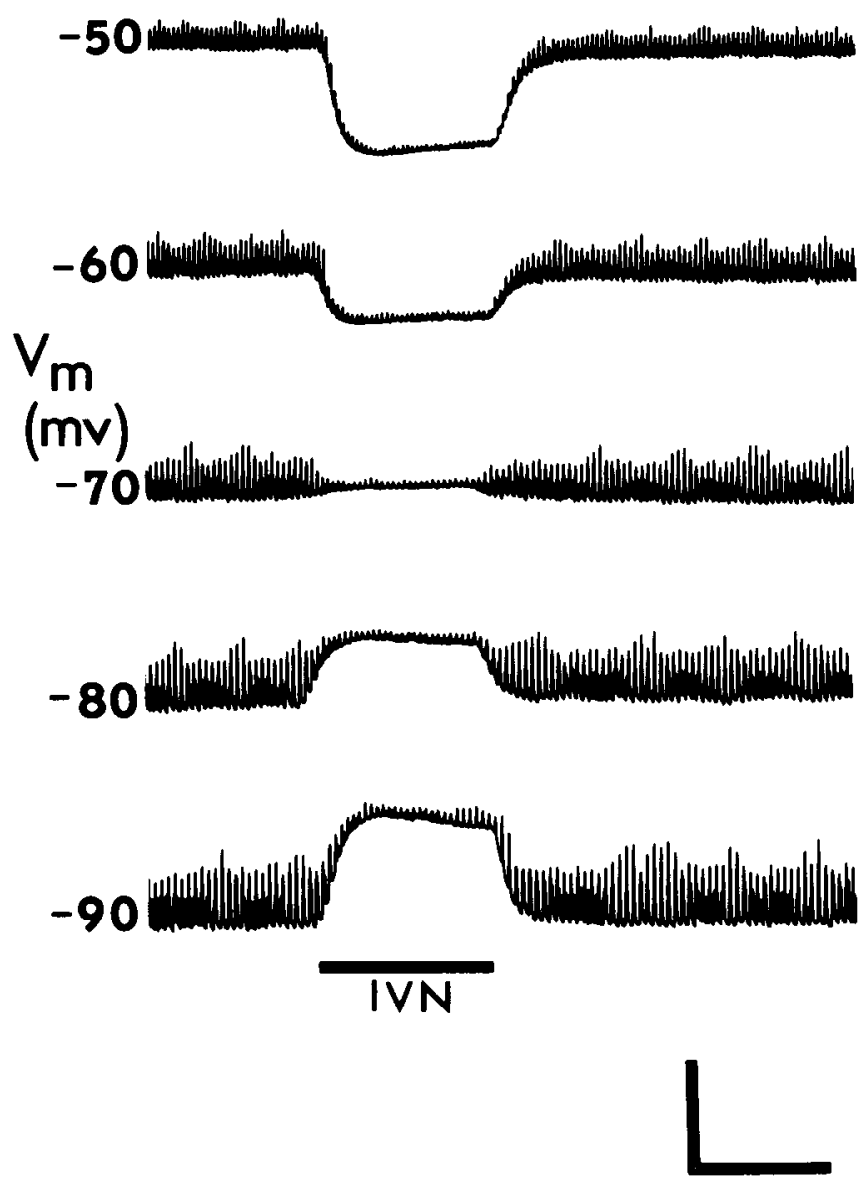

Figure 8. Apparent reversal potential of IVN through-fiber inhibitory synaptic potential. The IVN was stimulated extracellularly with a train at $40 \mathrm{~Hz}$ (bar) to produce a summed potential recorded intracellularly in an EX neuron. The membrane potential of the EX neuron was altered with a second 0.5 $\mathrm{M} \mathrm{K}_{2} \mathrm{SO}_{4}$ electrode. In this particular experiment, the apparent reversal potential (determined by plotting response amplitude versus membrane potential) was $-68 \mathrm{mV}$ and the resting potential was $-61 \mathrm{mV}$. Spontaneous postsynaptic potentials are visible in these recordings, and they are diminished in size during the through-fiber response because of the increased membrane conductance in the EX neuron. Scale bars $=10 \mathrm{mV}$, $4 \mathrm{sec}$.

and inhibitory responses (data not shown), as has been found by previous investigators (Marder and PaupardinTritsch, 1978; Bidaut, 1980; Russell and Hartline, 1981; Sigvardt and Mulloney, 1982a). Of the other antagonists, only pyrilamine had an effect. It blocked the throughfiber excitatory responses in the PD and cardiac dilator (CD2) neurons, but it did not appear to affect the inhibitory potentials in the PD and EX neurons. The effects of pyrilamine on the synaptic potentials in the PD and EX neurons are shown in Figure 10. The concentration of pyrilamine used here $\left(10^{-4} \mathrm{M}\right)$ did not affect the membrane resistance or action potential amplitude of stomatogastric neurons, but concentrations greater than $5 \times 10^{-4}$ did reduce action potential amplitude.

The IVN through-fiber synaptic potentials were also examined after desensitization of histamine receptors. Receptors were desensitized by perfusing the ganglion with $5 \times 10^{-4}$ or $10^{-3} \mathrm{M}$ histamine in saline. Receptors were defined as desensitized when the membrane voltage and conductance of a responsive neuron returned to control values in the presence of histamine. Somal receptors (examined with iontophoretic histamine application) desensitized within minutes, but neuropil receptors often took from 30 to 60 min to desensitize completely.

Desensitization of histamine receptors blocked the IVN through-fiber inhibitory potentials but did not appear to affect the excitatory responses (Fig. 11), nor did desensitization block other spontaneous inhibitory synaptic potentials in the ganglion. Desensitization and the block of through-fiber inhibitory potentials were irreversible in most preparations even after $5 \mathrm{hr}$ of wash with normal saline. But, in one preparation, the response to bath application of histamine returned, as did the through-fiber inhibitory potentials.

Histamine levels. Histamine was present in all nerves and ganglia but was distributed nonuniformly. This distribution is illustrated in Figure 12 and in Table II. Of the various nerves, the IVN contained the highest concentration of histamine. Most of the histamine in the nerves and ganglia appeared to be associated with neuronal tissue, rather than with the thick connective tissue sheath which surrounds the nerves and ganglia. Four

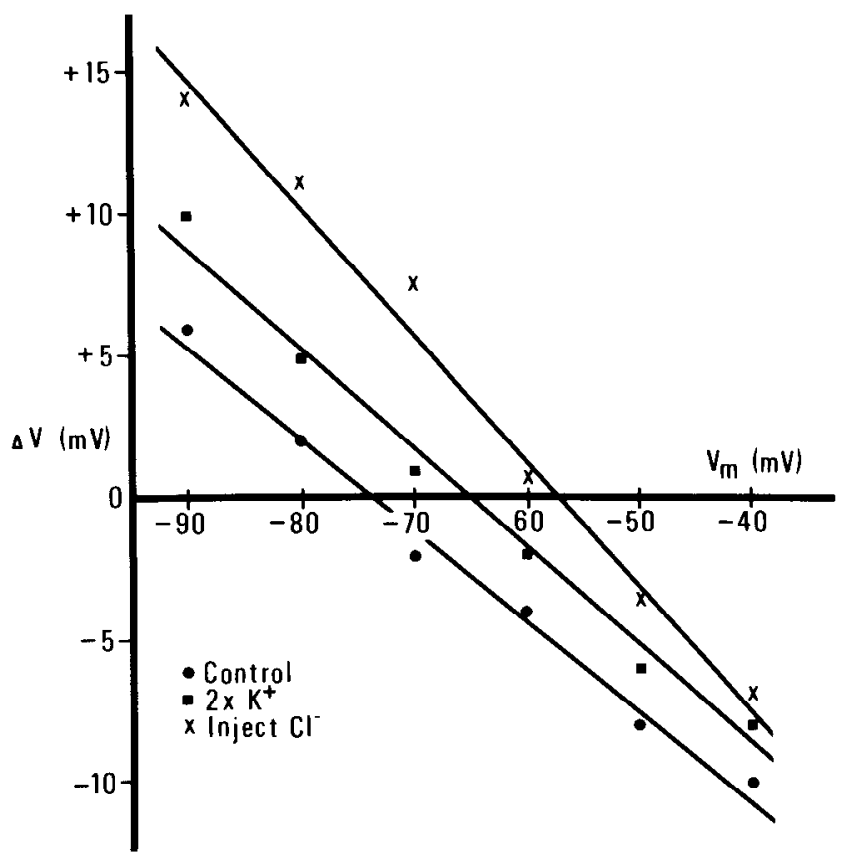

Figure 9. Plots of amplitudes of through-fiber inhibitory potentials versus membrane potential in an $\mathrm{EX}$ neuron in normal saline, in saline containing $2 \times \mathrm{K}^{+}\left(25 \mathrm{mM} \mathrm{K}^{+}\right)$, and after injection of $\mathrm{Cl}^{-}$ions. The ganglion was first perfused with $2 \times \mathrm{K}^{+}$and the reversal potential (point where line crosses abscissa) depolarized from $-73 \mathrm{mV}$ to $-65 \mathrm{mV}$, but the resting potential also depolarized from $-67 \mathrm{mV}$ to $-51 \mathrm{mV}$. After returning the ganglion to normal saline, the reversal and resting potentials returned to control values within $20 \mathrm{~min} . \mathrm{Cl}^{-}$ions were then injected by holding the cell at $-120 \mathrm{mV}$ for $15 \mathrm{~min}$ with a $3 \mathrm{M} \mathrm{KCl}$ electrode. The reversal potential depolarized from $-73 \mathrm{mV}$ to $-57 \mathrm{mV}$, and the resting potential hyperpolarized from -67 to $-69 \mathrm{mV}$. These potentials returned to control values within $10 \mathrm{~min}$ after terminating the injection. 
PD neuron
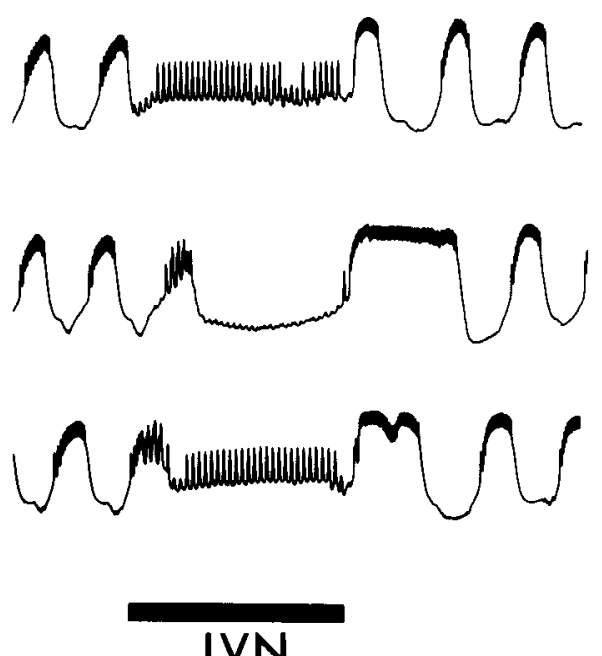

Control

EX neuron
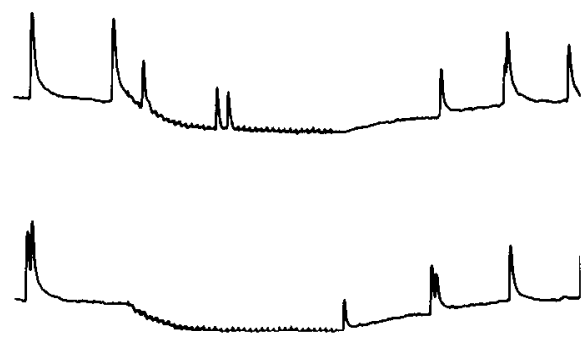

Wash

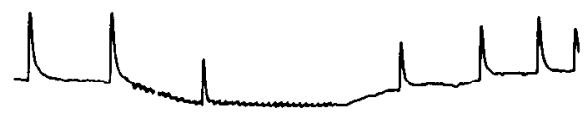

Figure 10. Effect of pyrilamine on through-fiber synaptic potentials. Intracellular recordings were made from PD (first panel) and EX (second panel) neurons, and the IVN was stimulated with a train at $20 \mathrm{~Hz}$ (bars). Top traces show postsynaptic responses in normal saline. Middle traces show the effect of $10^{-4} \mathrm{M}$ pyrilamine which had been perfused over the preparation for 8 min. Note in the PD neuron (first panel) that the excitatory component of the biphasic potential was blocked, revealing the inhibitory component. The inhibitory potentials in both the PD and EX neuron were unaffected by pyrilamine. Note also that the spontaneous excitatory potentials in the EX neuron were not blocked by pyrilamine, indicating that pyrilamine specifically abolished the through-fiber excitatory potentials. Bottom traces show that the excitatory component in the PD neuron returned after $30 \mathrm{~min}$ of wash with normal saline. The membrane potentials in all traces were the same, and were $-59 \mathrm{mV}$ in the PD neuron and $-61 \mathrm{mV}$ in the $\mathrm{EX}$ neuron. Scale bars $=20 \mathrm{mV}$ for $\mathrm{PD}, 5 \mathrm{mV}$ for $\mathrm{EX}, 0.4$ sec.

PD Neuron
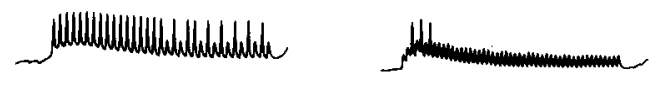

Control

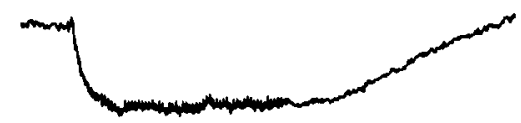

EX Neuron

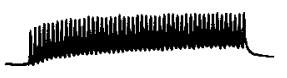

Desensitized

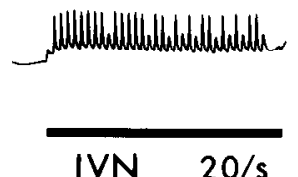

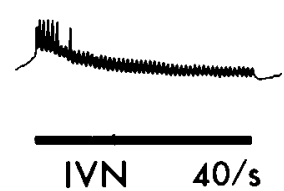

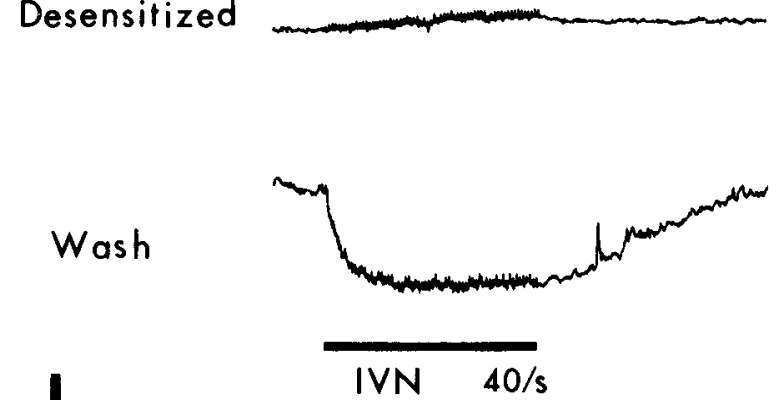

Figure 11. Effects of histamine receptor desensitization on the IVN through-fiber synaptic potentials. Intracellular recordings were made from PD (first two panels) and EX (third panel) neurons. The IVN was stimulated with trains at either 20 or $40 \mathrm{~Hz}$ (bars). Top traces show potentials before desensitization. Middle traces show potentials after histamine receptors were desensitized and the membrane conductances had returned to control values. The inhibitory potentials in both PD and EX neurons were blocked, whereas the excitatory component in the PD neuron was not affected. (Inhibitory potentials in the desensitized state were not present even when the membrane potentials were hyperpolarized and depolarized $20 \mathrm{mV}$ from rest.) Note also that, in the desensitized case, the small depolarizing "jump" at the beginning of the IV response was abolished. Bottom traces show that the inhibitory potentials returned following $5 \mathrm{hr}$ of wash with saline. The neurons were again responsive to histamine at this time point. Membrane potentials were constant in all traces, and were $-62 \mathrm{mV}$ in the PD neuron and $-65 \mathrm{mV}$ in the EX neuron. Scale bars $=20 \mathrm{mV}$ for PD, $5 \mathrm{mV}$ for EX, $0.5 \mathrm{sec}$. 


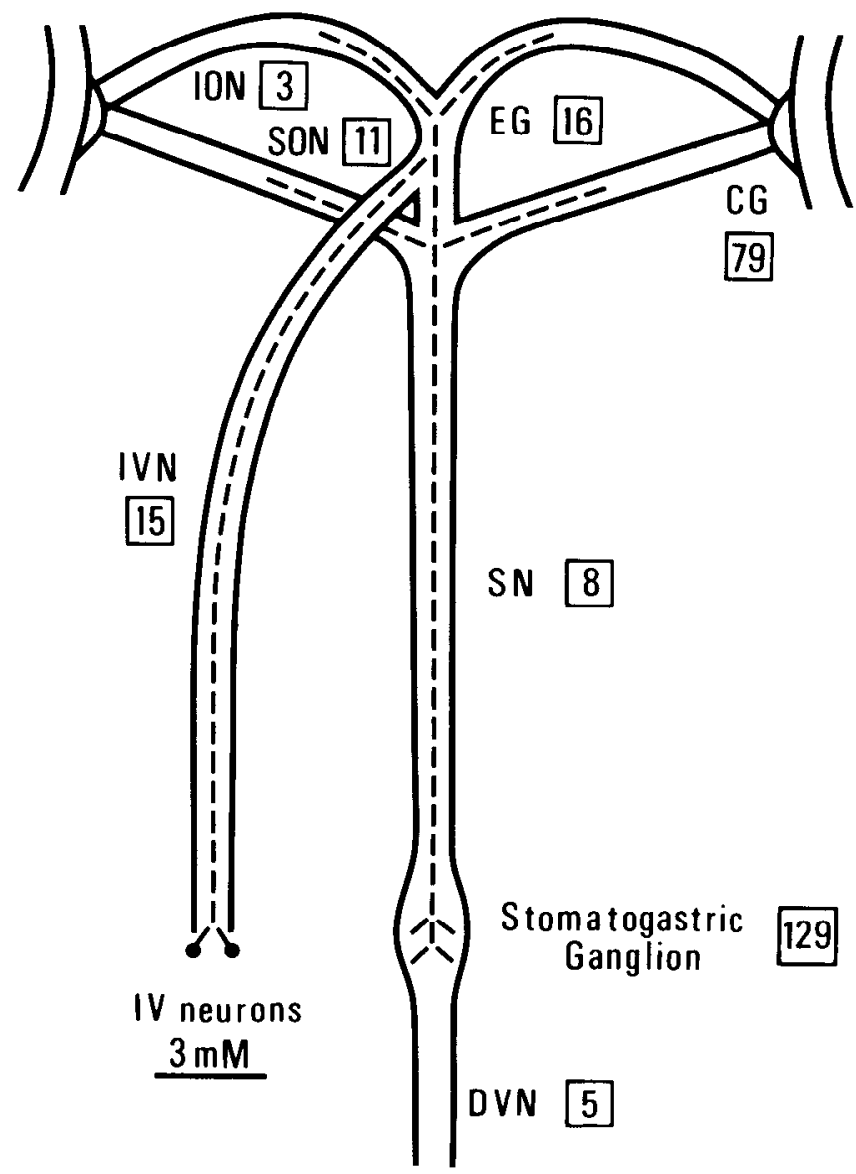

Figure 12. Diagrammatic representation of the stomatogastric nervous system showing the histamine concentrations in nerves and ganglia in nanomoles per gram of protein (boxes), and in the two IV neuron cell bodies ( $3 \mathrm{~mm}$ ). The IV neurons are located at the base of the inferior ventricular nerve $(I V N)$ in the brain and the pathways of their axons, the IVN throughfibers, are indicated here by the dashed line. The terminations of their branches in the SONs and IONs arc not known. ION, inferior esophageal nerve; $S O N$, superior esophageal nerve; $E G$, esophageal ganglion; $C G$, commissural ganglion; $S N$, stomatogastric nerve; $D V N$, dorsal ventricular nerve. Nomenclature is from Maynard and Dando (1974).

TABLE II

Histamine in ganglia and nerves of the stomatogastric nervous system Each value is the mean \pm SEM of the number of separate determinations $(n)$. The sensitivity of the assay was $0.02 \mathrm{pmol}$, and protein was measured using the Lowry method.

\begin{tabular}{lccc}
\hline \multirow{1}{*}{ Tissue } & \multicolumn{2}{c}{ Histamine Content } & \\
\cline { 2 - 3 } & $\begin{array}{c}\text { Picomoles } \\
\text { per Tissue }\end{array}$ & $\begin{array}{c}\text { Nanomoles per } \\
\text { gram of } \\
\text { Protein }\end{array}$ & $n$ \\
\hline Ganglia & & & \\
$\quad$ Commissural & $3.36 \pm 0.21$ & $79 \pm 11$ & 9 \\
Esophageal, anterior & $0.48 \pm 0.17$ & $12 \pm 4$ & 5 \\
Esophageal, posterior & $0.61 \pm 0.07$ & $24 \pm 4$ & 5 \\
$\quad$ Stomatogastric & $2.00 \pm 0.31$ & $129 \pm 23$ & 7 \\
Nerves & & & \\
$\quad$ Dorsal ventricular & $0.19 \pm 0.08$ & $5 \pm 2$ & 2 \\
Inferior esophageal & $0.25 \pm 0.09$ & $3 \pm 1$ & 3 \\
Inferior ventricular & $0.90 \pm 0.06$ & $15 \pm 2$ & 5 \\
$\quad$ Stomatogastric & $0.75 \pm 0.06$ & $8 \pm 1$ & 9 \\
Superior esophageal & $0.50 \pm 0.07$ & $11 \pm 1$ & 3 \\
\hline
\end{tabular}

samples of connective tissue sheaths were assayed: two from stomatogastric ganglia, one from an esophageal ganglion, and one from a commissural ganglion. Only one sample, a sheath from a stomatogastric ganglion, contained detectable histamine, and this was a small amount, 0.03 pmol.

Because the stomatogastric ganglion had the highest overall concentration of histamine, we determined the location of the histamine in this ganglion. The stomatogastric ganglion consists of an outer layer of neuronal cell bodies and a central region of neuropil (Maynard, 1971). Neuronal cell bodies from four stomatogastric ganglia were assayed. Six of the larger cells from one ganglion were chosen at random and were assayed individually. None of these cells contained detectable histamine (Table III). All of the visible cells from the other three ganglia were removed, and the cellular extracts from each ganglion were pooled and assayed together for histamine. Histamine was either undectable or present in only small amounts in these combined cells (Table III). The neuropil regions from these latter three ganglia were assayed separately and were found to contain relatively high concentrations of histamine, $236 \pm 70 \mathrm{nmol} /$ gm of tissue protein (mean $\pm \mathrm{SEM}$ ).

After locating the cell bodies of the IVN through-fibers in the brain (Claiborne, 1981b; Claiborne and Selverston, 1983), we assayed them for histamine. Because of their relatively small diameter $(30 \mu \mathrm{m})$ and the difficulty involved in dissecting them, we were able to assay only five of the six cells from three animals. Two cells were assayed individually and were found to contain 0.05 and $0.08 \mathrm{pmol}$ of histamine, respectively. The other three cells were assayed together and contained a total of 0.15 pmol of histamine. This corresponds to an average level of $0.05 \mathrm{pmol} / \mathrm{cell}$ body (Table III). Assuming that the cells are spherical and not correcting for the volume of the nucleus, the intracellular concentration was estimated to be approximately $3.0 \mathrm{mM}$. In contrast to these

\section{TABLE III}

Histamine in neuronal cell bodies

Of the five IV neuron cell bodies assayed, two were assayed separately and three were assayed together. Four clusters of unidentified cells located close to the IV neurons in the brain were also assayed. For the assays of stomatogastric ganglion (StG) neurons, six of the larger cell bodies from one stomatogastric ganglion were assayed individually, and the extracts of all visible cell bodies from each of three other StG were combined and then assayed. The total number of neurons assayed from each ganglion is noted in the far right column. Neurons were not identified for these assays. The detection levels of these assays were 0.02 or 0.03 pmol of histamine.

\begin{tabular}{lcc}
\hline \multirow{2}{*}{ Tissue } & \multicolumn{2}{c}{ Histamine Content } \\
\cline { 2 - 3 } & Picomoles & $n$ \\
\hline IV cell bodies & 0.056 & 5 \\
Clusters of brain neurons (5 to & $\mathrm{ND}^{\alpha}$ & 4 \\
$\quad$ & & \\
10 per cluster) & $\mathrm{ND}$ & 6 \\
Single StG neurons & & \\
Combined StG neurons & $\mathrm{ND}$ & 28 \\
StG 1 & 0.03 & 25 \\
StG 2 & 0.04 & 27 \\
StG 3
\end{tabular}

${ }^{a} \mathrm{ND}$, none detectable. 
measurable levels of histamine, histamine was not detected in four clusters of 5 to 10 neurons located near the IV neurons in the brain or in the connective tissue sheath surrounding the IV cells (Table III).

\section{Discussion}

Histamine response. Exogenous histamine elicits a response in 14 stomatogastric neurons. This response is inhibitory and is mediated by an increased conductance with a reversal potential near the resting membrane potential. The response appears to be mediated by receptors on the 14 neurons being examined, and it does not appear to be synaptically mediated because (1) the histamine pipette had to be within $20 \mu \mathrm{m}$ of the responsive soma to elicit a response, (2) there is no ultrastructural evidence of electrical or chemical synapses on the cell bodies or primary dendrites of stomatogastric neurons where histamine elicited a response (King, 1976), and (3) the response persists in calcium-free, high-magnesium saline which blocks chemical synaptic potentials in the ganglion (Marder and Paupardin-Tritsch, 1978).

Results of ionic manipulation experiments suggest that the histamine response is mediated primarily by an increase in chloride conductance, as the reversal potential shifts in the depolarizing direction in low-chloride saline and following intracellular chloride injection. It is possible that the response also involves a small increase in potassium conductance as (1) the depolarizing shift in low chloride is only $10 \mathrm{mV}$ and not the $17-\mathrm{mV}$ shift predicted by the Nernst equation, and (2) there is a small depolarizing reversal potential shift in high potassium. However, the first result could be the consequence of a high resting chloride permeability in lobster stomatogastric neurons. Previous reports have shown that lobster and crab stomatogastric neurons have high resting chloride permeabilities (Marder and Paupardin-Tritsch, 1978; Eisen and Marder, 1982), as do other lobster neurons (Julian et al., 1962; Freeman et al., 1966). In this study, resting membrane potentials changed when external or internal chloride concentrations were altered (Table I), indicating that these neurons are probably permeable to chloride. The second result, a 4-mV depolarizing shift in high potassium, may not be significant as the resting membrane potential depolarized by an even greater amount $(7 \mathrm{mV})$. Hence, although we cannot eliminate the possibility that potassium is involved in the response, its role appears to be minor as compared to that of chloride.

Pharmacological experiments showed that the histamine receptors on lobster stomatogastric neurons are different from the histamine receptors on mammalian central neurons. The lobster histamine responses are not blocked by either $\mathrm{H}_{1}$ or $\mathrm{H}_{2}$ histamine antagonists, whereas mammalian receptors mediating inhibitory histamine responses are blocked by $\mathrm{H}_{2}$ antagonists (Haas and Bucher, 1975; Geller, 1976). However, the lobster receptors do appear to be similar to one type of histamine receptor found on neurons in the central nervous system of Aplysia californica. This Aplysia receptor also mediates an inhibitory response which involves a chloride-conductance increase, is not blocked by $\mathrm{H}_{1}$ or $\mathrm{H}_{2}$ antagonists, and is blocked by curare (Gruol and Weinreich, 1979).
Although the histamine response is blocked by curare, the site of curare's action on lobster neurons is presently unclear. Work on mammalian and molluscan neurons suggests that curare acts on chloride channels rather than on transmitter-specific receptor molecules (Carpenter et al., 1977; Ascher et al., 1979), but evidence obtained from the lobster shows that curare does not block all chloride-mediated responses. In the lobster stomatogastric system, curare does not block a chloride-mediated GABA response in neurons, nor a chloride-mediated glutamate response in muscles (Marder and PaupardinTritsch, 1978; Lingle and Marder, 1981). However, curare's value as a histamine antagonist in the lobster is limited because it does block a depolarizing acetylcholine response in stomatogastric neurons (Marder and Paupardin-Tritsch, 1978).

IVN through-fiber synaptic responses. The synaptic potentials elicited by the IVN through-fibers in stomatogastric ganglion neurons have been described in detail elsewhere (Dando and Selverston, 1972; Russell and Hartline, 1981; Sigvardt and Mulloney, 1982a). Here we examined a few of their properties in order to compare them to the properties of the histamine response.

The reversal potential of the inhibitory synaptic response was found to be approximately $10 \mathrm{mV}$ hyperpolarized from the resting potential, but this was determined by recording from cell bodies. Owing to the cable properties of stomatogastric neurons and the location of synaptic sites on axonal branches (King, 1976; Miller, 1980 ), the value of a synaptic reversal potential recorded in the soma will be more hyperpolarized than the actual reversal potential at the synaptic site (Calvin, 1969; Joyner et al., 1975; Llinás and Nicholson, 1976). Miller (1980) showed that a voltage change induced in a stomatogastric cell body attenuates by a factor between 0.45 and 0.79 before it reaches the synaptic area, thereby causing reversal potentials to appear to be farther from the resting potentials than they actually are. This means that the actual reversal potential of the through-fiber inhibitory response is several millivolts closer to the resting potential than the $-10 \mathrm{mV}$ measured here.

The ionic manipulation experiments suggest that the inhibitory response to through-fiber stimulation is due primarily to an increased chloride conductance as the reversal potential depolarizes following injection of chloride ions. The response also may include a small conductance increase to potassium, as the reversal potential depolarized a slight amount in the presence of two times the normal potassium concentration. However, this latter shift may be due to the high resting chloride conductance in stomatogastric neurons (see previous section).

Previous pharmacological reports indicated that both the inhibitory and excitatory IVN through-fiber potentials are reversibly blocked by curare but not by picrotoxin (Marder and Paupardin-Tritsch, 1978; Bidaut, 1980; Russell and Hartline, 1981; Sigvardt and Mulloney, 1982a), and we confirmed these reports (data not shown). Of the histamine antagonists tested on these synaptic potentials, only pyrilamine had an effect. It appeared to block the excitatory synaptic potentials, but it did not block the inhibitory potentials. Although we cannot elim- 
inate the possibility that the excitatory potentials were abolished by a presynaptic block in some of the throughfiber branches, this seems unlikely because the inhibitory potentials persisted in the presence of pyrilamine.

Desensitization of histamine receptors had an effect on the through-fiber potentials which was opposite to that of pyrilamine. With the histamine receptors desensitized, the through-fiber inhibitory potentials were abolished, but the excitatory potentials were not affected. Again, the possibility of presynaptic action potential blockade cannot be ruled out by our data, but it seems improbable because the excitatory potentials remained.

Histamine response and the IVN through-fiber synaptic responses. In this study, only an inhibitory response to exogenous histamine was found in stomatogastric neurons. Here we compare the characteristics of that response to the IVN through-fiber inhibitory synaptic potentials. The through-fibers also elicit other effects in stomatogastric neurons which are considered at the end of this section.

First, of the 30 neurons in the stomatogastric ganglion, only 14 respond to histamine. These same 14 neurons are the only cells which receive inhibitory synaptic potentials from the IVN through-fibers (Dando and Selverston, 1972; Selverston et al., 1976; Sigvardt and Mulloney, 1982a), either as single component inhibitory potentials (in the four GM, two LPG, and five EX neurons), or as part of biphasic excitatory/inhibitory potentials (in the two $\mathrm{PD}$ neurons and the one $\mathrm{AB}$ neuron).

Second, both the exogenous histamine response and the through-fiber inhibitory synaptic potentials are mediated by increased conductances which are primarily increased chloride conductances. Because of the problems in obtaining precise reversal potentials for stomatogastric synaptic responses (see previous section), it is difficult to compare directly the reversal potentials of the histamine and synaptic responses. However, both are within several millivolts of the resting membrane potentials, and both behave similarly following changes in chloride and potassium ion concentrations.

Third, the pharmacological data show that none of the histamine $\mathrm{H}_{1}$ or $\mathrm{H}_{2}$ antagonists block either the histamine response or the inhibitory through-fiber synaptic potentials, whereas curare does block both the histamine response and the through-fiber synaptic responses. Furthermore, the inhibitory synaptic response is abolished when histamine receptors are desensitized. This desensitization effect appears to be specific for the throughfiber inhibitory potentials as other synaptic potentials in the ganglion, including the excitatory through-fiber potentials, are unaffected.

These comparisons show that several similarities exist between the histamine response and the IVN throughfiber inhibitory synaptic potentials. The through-fibers, however, also elicit excitatory synaptic potentials in the $\mathrm{PD}, \mathrm{AB}, \mathrm{CD} 2$ neurons, and in interneuron 1 (Dando and Selverston, 1972; Selverston et al., 1976; Claiborne, 1981b; Russell and Hartline, 1981; Sigvardt and Mulloney, 1982a). In this study we did not find any excitatory responses in the course of applying histamine to neuronal somata, but J. Eisen (personal communication) has obtained preliminary results showing that iontophoretic application of histamine to stomatogastric neuropil processes elicits a depolarizing response in a PD neuron. It will be of interest to see if this depolarizing response either (1) desensitizes, as the through-fiber excitatory potentials are not abolished when the receptors mediating the inhibitory histamine response are desensitized; or (2) is blocked by pyrilamine, because we found that the excitatory through-fiber potentials in the PD neuron are abolished by pyrilamine, even though the inhibitory through-fiber potentials are not affected. Pyrilamine is a histamine $\mathrm{H}_{1}$ antagonist which appears to block an excitatory, but not an inhibitory, histamine synaptic potential in Aplysia (R. McCaman, personal communication), and which blocks excitatory, but not inhibitory, responses to exogenous histamine in mammalian and molluscan neurons (Haas, 1974; Carpenter and Gaubatz, 1975; Geller, 1976; Gotow et al., 1980).

Russell and Hartline (1981) have reported that stimulation of the IVN through-fibers can unmask bursting properties in certain stomatogastric neurons. At present, there is no evidence to suggest that histamine induces bursting properties in stomatogastric neurons. It may be that such an effect would not have been visible with our procedures. We did note that the depolarizing "jump" which occurs at the beginning of the PD response disappeared when histamine receptors were desensitized (Fig. 11), but this finding was not examined in detail. If histamine is not used by the through-fibers to mediate their burst-inducing effects, it is possible that (1) an interposed neuron makes electrical connections with both the through-fibers and stomatogastric neurons, or (2) the through-fibers use two transmitters (Hokfelt et al., 1980). The first possibility has not been rigorously tested but appears unlikely on the basis of collision experiments of action potentials in the IVN and SN (Dando and Selverston, 1972) and the known connections among neurons in the stomatogastric ganglion (Selverston et al., 1976; Russell and Hartline, 1981).

Histamine levels. Histamine is distributed unevenly throughout the lobster stomatogastric nervous system. Its distribution appears to correlate with the axon trajectories and terminal arborizations of the IVN throughfibers (Fig. 12 and Table III). The through-fibers are two of only nine axons in the IVN, and, of the nerves, the IVN has the highest histamine concentration. The through-fibers travel from the IVN to the esophageal ganglion, where they make some synaptic connections (Vedel and Moulins, 1977). From there they send branches into the superior and inferior esophageal nerves (SONs and IONs) and then enter the SN (Selverston et al., 1976; Kushner, 1979a). The SN is approximately the same length as the IVN and, as can be seen from Table III, contains approximately the same absolute amount of histamine as does the IVN. The throughfibers terminate in the neuropil region of the stomatogastric ganglion which is rich in histamine. There is no evidence that the through-fibers continue into the dorsal ventricular nerve (DVN), and this nerve has a low histamine concentration.

The through-fibers probably do not account for all of the histamine found in the stomatogastric system. As just noted, they do not enter the DVN, but this nerve 
contains some histamine. Similarly, although they send branches into the SONs and IONs, it is not known if these branches make synaptic connections in the commissural ganglia which do have high histamine concentrations.

Of the individual neurons assayed for histamine, only the IV neurons contained detectable histamine. Histamine was not present in clusters of neurons located near the IV neurons in the brain, in individual stomatogastric neurons, nor in the combined extracts of all visible cells from one stomatogastric ganglion. Although small amounts of histamine were detected in the combined extracts of all cells from each of two other stomatogastric ganglia, the amounts were less than the amounts of histamine in one IV neuron cell body. This is not due to the relative size of the somata examined since most of the stomatogastric cells are greater than $60 \mu \mathrm{m}$ in diameter, whereas the IV neurons are only $30 \mu \mathrm{m}$ in diameter.

The presence of endogenous histamine at a concentration of approximately $3.0 \mathrm{mM}$, therefore, appears to be a distinguishing feature of the IV neurons. This concentration is within the range of histamine concentrations in Aplysia neurons, where there is significant evidence that histamine functions as a neurotransmitter (Weinreich, 1977; Weinreich and Yu, 1977; McCaman and McKenna, 1978; McCaman and Weinreich, 1982), and within the range of other putative neurotransmitter concentrations in invertebrate cells (Kehoe and Marder, 1976). "Histaminergic" neurons in A. californica have histamine concentrations between 0.3 and $4.2 \mathrm{~mm}$ (Weinreich et al., 1975; Ono and McCaman, 1980), a putative cholinergic cell in Aplysia, L10, contains 0.33 mM acetylcholine (McCaman et al., 1973), and lobster inhibitory neurons that use GABA as a transmitter contain 15 mM GABA (Otsuka et al., 1967).

Role of histamine in the stomatogastric nervous system. Results presented here suggesting that the IV neurons may use histamine as a transmitter would be consistent with the general hypothesis that monoamines serve to control patterned activity in the stomatogastric system. The IV neurons can exert at least two forms of control over the stomatogastric ganglion. At low frequencies of firing (below $30 \mathrm{~Hz}$ ), they increase the rate of ganglionic activity and can cause phase shifts of some neurons in the pyloric system (J. Ayers and A. I. Selverston, manuscript in preparation). At high frequencies of firing (above $30 \mathrm{~Hz}$ ), they cause a complete interruption of normal stomatogastric activity by temporarily inhibiting some neurons while causing others to fire tonically. Such bursts of high frequency firing occur spontaneously in vitro and can be induced by stretching the pyloric region of the stomach in a semi-intact preparation (Sigvardt and Mulloney, 1982b). The behavioral effect of these bursts is to hold the muscles of the pyloric and gastric mill stomach regions in a motionless state. Sigvardt and Mulloney have proposed that this is a "swallowing" reflex which serves to force food particles from one stomach region to another and may be an important part of normal foregut functioning.

Previous studies of the lobster stomatogastric nervous system have identified the neurotransmitters used by some neurons with known functions. Acetylcholine and glutamate appear to be used as transmitters by motor neurons (Marder, 1976; Marder and Paupardin-Tritsch, 1978; Lingle, 1980), and glutamate may be used by at least one interneuron (Eisen and Marder, 1982; E. Marder and J. S. Eisen, submitted for publication). Studies of biogenic amines suggest that amines may be associated with neurons involved in the modulation of patterned activity. Dopamine is present in neurons in the commissural ganglia and in fibers in the stomatogastric nerve, and it affects the rate of activity of neurons in the stomatogastric ganglion which control pyloric movements (Kushner and Maynard, 1977; Anderson, 1980; Anderson and Barker, 1981; Kushner and Barker, 1983). Octopamine may act in a similar fashion on neurons controlling gastric mill movements (M. Wadepuhl, personal communication). Furthermore, serotonin is present in the stomatogastric system (H. Karten and A. I. Selverston, unpublished results; Beltz et al., 1983), and exogenous serotonin increases the rate of activity of ganglionic neurons (Anderson, 1980).

In summary, we have shown that the neurons in the stomatogastric ganglion which receive inhibitory potentials from the IVN through-fibers are inhibited by exogenous histamine, that the distribution of histamine in stomatogastric tissue correlates with the anatomy of the through-fibers, and that histamine is present in the cell bodies of the IV neurons but is undetectable in other neuronal somata of the stomatogastric system. These results provide suggestive evidence that histamine may be a neurotransmitter in the lobster and, furthermore, that it may play a role in controlling rhythmic activity in the stomatogastric nervous system.

\section{References}

Anderson, W. W. (1980) Synaptic mechanisms generating nonspiking network oscillations in the stomatogastric ganglion of the lobster Panulirus interruptus. Ph.D. dissertation, Department of Biology, University of Oregon, Eugene, OR.

Anderson, W. W., and D. L. Barker (1981) Synaptic mechanisms that generate network oscillations in the absence of discrete postsynaptic potentials. J. Exp. Zool. 216: 187-191.

Ascher, P., W. A. Large, and H. P. Rang (1979) Studies on the mechanism of action of acetylcholine antagonists on rat parasympathetic ganglion cells. J. Physiol. (Lond.) 295: 139170.

Beltz, B. S., J. S. Eisen, R. Flamm, R. Harris-Warwick, S. Hooper, and E. Marder (1983) Serotonergic innervation of the stomatogastric ganglion of Homarus americanus, Cancer irroratus and Panulirus interruptus. Soc. Neurosci. Abstr. 9: 76.

Bidaut, M. (1980) Pharmacological dissection of pyloric network of the lobster stomatogastric ganglion using picrotoxin. J. Neurophysiol. 44: 1089-1101.

Calvin, W. H. (1969) Dendritic synapses and reversal potentials: Theoretical implications of the view from the soma. Exp. Neurol. 24: 248-264.

Carpenter, D. O. and G. L. Gaubatz (1975) $\mathrm{H}_{1}$ and $\mathrm{H}_{2}$ histamine receptors on Aplysia neurons. Nature 254: 343-344.

Carpenter, D. O., J. W. Swann, and P. J. Yarowsky (1977) Effect of curare on responses to different putative neurotransmitters in Aplysia neurons. J. Neurobiol. 8: 119-132.

Claiborne, B. J. (1980a) Histamine inhibits identified neurons in the spiny lobster. Soc. Neurosci. Abstr. 6: 626. 
Claiborne, B. J. (1980b) A histamine response in lobster neurons is not blocked by either histamine $\mathrm{H}_{1}$ or $\mathrm{H}_{2}$ antagonists. Neurosci. Lett. Suppl. 5: 237.

Claiborne, B. J. (1981a) Endogenous histamine in the lobster stomatogastric nervous system. Soc. Neurosci. Abstr. 7: 316.

Claiborne, B. J. (1981b) Histamine as a putative neurotransmitter in the lobster stomatogastric nervous system. Ph.D. dissertation, Biology Department, University of California at San Diego.

Claiborne, B. J., and A. I. Selverston (1983) Localization of stomatogastric IV neuron cell bodies in lobster brain. J. Comp. Physiol., in press.

Dando, M. R., and A. I. Selverston (1972) Command fibers from the supra-oesophageal ganglion to the stomatogastric ganglion in Panulirus argus. J. Comp. Physiol. 78: 138-175.

Eisen, J. S., and E. Marder (1982) Mechanisms underlying pattern generation in lobster stomatogastric ganglion as determined by selective inactivation of identified neurons. III. Synaptic connections of electrically coupled pyloric neurons. J. Neurophysiol. 48: 1392-1415.

Freeman, A. R., J. P. Reuben, P. W. Brandt, and H. Grundfest (1966) Osmometrically determined characteristics of the cell membrane of squid and lobster giant axons. J. Gen. Physiol. 50: $423-445$.

Geller, H. M. (1976) Effects of some putative neurotransmitters on unit activity of tuberal hypothalamic neurons in vitro. Brain Res. 108: 423-430.

Gotow, T., C. T. Kirkpatrick, and T. Tomita (1980) Excitatory and inhibitory effects of histamine on molluscan neurons. Brain Res. 196: 151-167.

Graubard, K. (1978) Synaptic transmission without action potentials: Input-output properties of a nonspiking presynaptic neuron. J. Neurophysiol. 41: 1014-1025.

Gruol, D. L., and D. Weinreich (1979) Two pharmacologically distinct histamine receptors mediating membrane hyperpolarization on identified neurons of Aplysia californica. Brain Res. 162: 281-301.

Haas, H. L. (1974) Histamine: Action on single hypothalamic neurons. Brain Res. 76: 363-366.

Haas, H. L., and U. M. Bucher (1975) Histamine $\mathrm{H}_{2}$-receptors on single central neurones. Nature 255: 634-635.

Hokfelt, T., O. Johansson, A. Ljungdahl, J. M. Lundberg, and M. Schultzberg (1980) Peptidergic neurons. Nature 284: 515 521.

Joyner, R. W., J. W. Moore, and F. Ramon (1975) Axon voltage clamp simulations. III. Postsynaptic region. Biophys. J. 15: $37-45$.

Julian, F. J., J. W. Moore, and D. E. Goldman (1962) Membrane potentials of the lobster giant axon obtained by use of the sucrose-gap technique. J. Gen. Physiol. 45: 1195-1216.

Kehoe, J., and E. Marder (1976) Identification and effects of neural transmitters in invertebrates. Annu. Rev. Pharmacol. 16: $245-268$.

King, D. G. (1976) Organization of crustacean neuropil. I. Patterns of synaptic connections in lobster stomatogastric ganglion. J. Neurocytol. 5: 207-237.

Kushner, P. D. (1979a) Location of interganglionic neurons in the stomatogastric system of the spiny lobster. J. Neurocytol. 8: 81-94.

Kushner, P. D. (1979b) The presence and function of dopamine in the lobster stomatogastric nervous system: The generation and regulation of motor rhythms. Ph.D. dissertation, University of Oregon, Eugene, OR.

Kushner, P. D., and D. L. Barker (1983) A neurochemical description of the dopaminergic innervation of the stomatogastric ganglion of the spiny lobster. J. Neurobiol. 14: 17-28.

Kushner, P. D., and E. A. Maynard (1977) Localization of monoamine fluorescence in the stomatogastric nervous system of lobsters. Brain Res. 129: 13-28.

Kushner, P. D., and J. Ono (1978) Endogenous dopamine in the stomatogastric ganglion and a single, identified neuron of the commissural ganglion. Soc. Neurosci. Abstr. 4: 198.

Lingle, C. (1980) The sensitivity of decapod foregut muscles to acetylcholine and glutamate. J. Comp. Physiol. 138: 187-199.

Lingle, C., and E. Marder (1981) A glutamate-activated chloride conductance on a crustacean muscle. Brain Res. 212: 481488.

Llinás, R., and C. Nicholson (1976) Reversal properties of climbing fiber potential in cat Purkinje cells: An example of a distributed synapse. J. Neurophysiol. 39: 311-323.

Marder, E. (1976) Cholinergic motor neurones in the stomatogastric system of the lobster. J. Physiol. (Lond.) 257: 63-86.

Marder, E., and D. Paupardin-Tritsch (1978) The pharmacological properties of some crustacean neuronal acetylcholine, $\alpha$-aminobutyric acid, and L-glutamate responses. J. Physiol. (Lond.) 280: 213-236.

Maynard, E. M. (1971) Electron microscopy of the stomatogastric ganglion in the lobster Homarus americanus. Tissue Cell 3: $137-160$.

Maynard, D. M., and M. R. Dando (1974) The structure of the stomatogastric neuromuscular system in Callinectes sapidus, Homarus americanus and Panulirus argus (Decapoda Crustacea). Philos. Trans. R. Soc. I ond. Biol. 268: 161-220.

Maynard, D., and K. Walton (1975) Effects of maintained depolarization of presynaptic neurons on inhibitory transmission in lobster neuropil. J. Comp. Physiol. 97: 215-243.

McCaman, R. E., and D. G. McKenna (1978) Monosynaptic connections hetween histamine-containing neurons and their various follower cells. Brain Res. 141: 165-171.

McCaman, R. E., and D. Weinreich (1982) On the nature of histamine-mediated slow hyperpolarizing synaptic potentials in identified molluscan neurons. J. Physiol. (Lond.) 328: 485506.

McCaman, R. E., D. Weinreich, and H. Borys (1973) Endogenous levels of acetylcholine and choline in individual neurons of Aplysia. J. Neurochem. 21: 473-476.

Miller, J. P. (1980) Mechanisms underlying pattern generation in the lobster stomatogastric ganglion. Ph.D. dissertation, Department of Biology, University of California at San Diego.

Miller, J. P., and A. I. Selverston (1982a) Mechanisms underlying pattern generation in lobster stomatogastric ganglion as determined by selective inactivation of identified neurons. II. Oscillatory properties of pyloric neurons. J. Neurophysiol. 48: 1378-1391.

Miller, J. P., and A. I. Selverston (1982b) Mechanisms underlying pattern generation in lobster stomatogastric ganglion as determined by selective inactivation of identified neurons. IV. Network properties of pyloric system. J. Neurophysiol. 48: 1416-1432.

Morris, J., and D. M. Maynard (1970) Recordings from the stomatogastric nervous system in intact lobsters. Comp. Biochem. Physiol. 33: 969-974.

Mulloney, B., and A. I. Selverston (1974) Organization of the stomatogastric ganglion in the spiny lobster. I. Neurons driving the lateral teeth. J. Comp. Physiol. 91: 1-32.

Ono, J. K., and R. E. McCaman (1980) Identification of additional histaminergic neurons in Aplysia: Improvement of single cell isolation techniques for in tandem physiological and chemical studies. Neuroscience 5: 835-840.

Otsuka, M., E. A. Kravitz, and D. D. Potter (1967) Physiological and chemical architecture of a lobster ganglion with particular reference to gamma-aminobutyrate and glutamate. J. Neurophysiol. 30: 725-752. 
Raper, J. (1980) Non-impulse mediated synaptic transmission in the stomatogastric ganglion of the spiny lobster. Ph.D. dissertation, Department of Neurosciences, University of California at San Diego.

Russell, D. F. (1976) Rhythmic excitatory inputs to the lobster stomatogastric ganglion. Brain Res. 101: 582-588.

Russell, D. F. (1979) CNS control of pattern generators in the lobster stomatogastric ganglion. Brain Res. 177: 598-602.

Russell, D. F., and D. K. Hartline (1981) A multiaction synapse evoking both EPSP's and enhancement of endogenous bursting. Brain Res. 223: 19-38.

Russell, D. F., and D. K. Hartline (1982) Slow active potentials and bursting motor patterns in pyloric network of the lobster, Panulirus interruptus. J. Neurophysiol. 48: 914-937.

Schwartz, J. C. (1977) Histaminergic mechanisms in brain. Annu. Rev. Pharmacol. Toxicol. 17: 325-39.

Schwartz, J. C., G. Barbin, M. Baudry, M. Garbarg, M. P. Martes, and M. Verdiere (1979) Metabolism and function of histamine in the brain. Curr. Dev. Psychopharmacol. 5: 173261.

Schwartz, J. C., H. Pollard, and T. T. Quach (1980) Histamine as a neurotransmitter in mammalian brain: Neurochemical evidence. J. Neurochem. 35: 26-33.

Selverston, A. I., D. F. Russell, J. P. Miller, and D. G. King (1976) The stomatogastric nervous system: Structure and function of a small neural network. Prog. Neurobiol. 7: 215290.

Selverston, A. I., and J. P. Miller (1980) Mechanisms underlying pattern generation in lobster stomatogastric ganglion as determined by selective inactivation of identified neurons. I. Pyloric system. J. Neurophysiol. 44: 1102-1121.

Sigvardt, K. A., and B. Mulloney (1982a) Properties of synapses made by IVN command-interneurons in the stomatogastric ganglion of the spiny lobster, Panulirus interruptus. J. Exp. Biol. 97: 153-168.

Sigvardt, K. A., and B. Mulloney (1982b) Sensory alteration of motor patterns in the stomatogastric nervous system of the spiny lobster, Panulirus interruptus. J. Exp. Biol. 97: 137152.

Taylor, K. M., and S. H. Snyder (1972) Isotopic microassay of histamine, histidine, histidine decarboxylase and histamine methyltransferase in brain tissue. J. Neurochem. 19: 13431358.

Vedel, J. P., and M. Moulins (1977) Functional properties of interganglionic motor neurons in the stomatogastric nervous system of the rock lobster. J. Comp. Physiol. 118: 307-325.

Weinreich, D. (1977) Synaptic responses mediated by identified histamine-containing neurons. Nature 267: 854-856.

Weinreich, D. (1978) Histamine-containing neurons in Aplysia. In Biochemistry of Characterized Neurons, N. N. Osborne, ed., pp. 153-175, Pergamon Press, Oxford.

Weinreich, D., and Y. T. Yu (1977) The characterization of histidine decarboxylase and its distribution in nerves, ganglia and in single neuronal cell bodies from the CNS of Aplysia californica. J. Neurochem. 28: 361-370.

Weinreich, D., C. Weiner, and R. McCaman (1975) Endogenous levels of histamine in single neurons isolated from CNS of Aplysia californica. Brain Res. 84: 341-345. 